\title{
Regulators, culture media and types of lights in vitro lavender culture
}

\author{
Rayssa Camargo de Oliveira ${ }^{1^{*}}$ (iD) Simone Abreu Asmar ${ }^{1}$ Herick Fernando de Jesus Silva ${ }^{1}$ \\ Tâmara Prado de Morais $^{1}$ José Magno Queiroz Luz ${ }^{1}$
}

${ }^{1}$ Instituto de Ciências Agrárias, Universidade Federal de Uberlândia (UFU), Campus Glória, 38410337, Uberlândia, MG, Brasil. E-mail: rayssacamargo@yahoo.com.br. "Corresponding autor.

ABSTRACT: Lavender is an aromatic ornamental plant that is used widely in the perfume, pharmaceutical, cosmetical and food industries.
That is why it is important to study ways to promote a production of lavender raw material. For this, four experiments were carried out in
order to study the germination and initial in vitro development of lavender. In the first part the efficiency of the use of hydrogen peroxide in the
pre-treatment of seeds inoculated in culture media with different concentrations of gibberellic acid was evaluated. Besides that, the influence
of the use of Growlux lamps and white fluorescent lamps on plantlets cultivated in MS and LS media at salts concentrations of 50 and $100 \%$
was evaluated. Finally, the effect of the gibberellic acid, putrescine, spermine and spermidine in different concentrations was evaluated. Better
results were estimated when hydrogen peroxide pretreatment was applied to the seeds with subsequent inoculation in a medium containing
$2,5 \mathrm{mg} L^{-1}$ of gibberellic acid. The use of Growlux lamps did not influence the characteristics observed when compared to the use of white
fluorescent lamps, however it was concluded that the species develops more in a LS medium. Concerning the use of polyamines was found that
germination, aerial part and number of leaves of the seedlings were generally favored at the concentration of 0,5 mg L L $L^{-1}$ except when spermine
was applied, which resulted in a lower number of leaves under this condition.

Key words: Lavandula angustifolia, tissue culture, GA, polyamines, lamp.

Reguladores, meios de cultura e tipos de luzes na cultura de lavanda in vitro

RESUMO: Lavanda é uma planta ornamental aromática que é amplamente utilizada nas indústrias de perfumaria, farmacêutica, cosmética e alimentícia e por isso é importante estudar maneiras de promover a produção dessa matéria-prima. Para tanto, foram realizados quatro experimentos com o objetivo de estudar a germinação e o desenvolvimento inicial in vitro da lavanda. No primeiro experimento testou-se a eficiência do uso de peróxido de hidrogênio no pré-tratamento de sementes inoculadas em meios de cultura com diferentes concentrações de ácido giberélico. Além disso, foi avaliado a influência do uso de lâmpadas Growlux e de lâmpadas fluorescentes brancas em plântulas cultivadas nos meios MS e LS em concentrações de sais de 50 e 100\%. Por fim, também estudou-se o efeito dos reguladores ácido giberélico, putrescina, espermina e espermidina em diferentes concentrações. Melhores resultados foram encontrados quando o pré-tratamento com peróxido de hidrogênio foi aplicado às sementes com posterior inoculação em meio contendo $2,5 \mathrm{mg} \mathrm{L}^{-1}$ de ácido giberélico. O uso de lâmpadas Growlux não influenciou as características avaliadas quando comparado ao uso de lâmpadas fluorescentes brancas, entretanto observou-se que as espécies se desenvolvem melhor em meio LS. Com relação ao uso de poliaminas, verificou-se que a germinação, parte aérea e número de folhas das plântulas

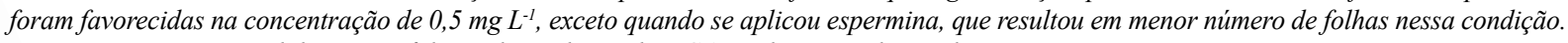
Palavras chave: Lavandula angustifolia, cultura de tecidos, $G A_{3}$, poliaminas, lâmpadas.

\section{INTRODUCTION}

The species Lavandula angustifolia Mill. (Lamiaceae) is an important medicinal and aromatic plant, used mainly in the extraction of essential oil and also as ornamental and bee plant. Its essential oil, obtained from the distillation of flowers, stems and leaves, is important for cosmetic, pharmaceutical and perfumery industries (MACHADO et al., 2013).
It originates from the Mediterranean Sea region, and is cultivated on a larger scale in European countries such as France (DDTD, 2010), in Brazil it is occasionally cultivated in the South as an ornamental plant and for medicinal purposes, but cultivation of this species in large scale is still incipient, as well as the extraction of its essential oil, since it is a moderate climate plant. However, SILVA et al. (2017) pointed out that it is possible to obtain good propagative 
material yields of these species, even in tropical and weathered soils using technology and innovation, such as tissue culture.

Almost absolute control of morphogenesis from in vitro explants is one of the main characteristics of plant tissue culture (TERMIGNONI, 2005). Thus, it is important to study in detail what are the most suitable medium culture, its components, and sources of light for each species. The LS (LINSMAIER \& SKOOG, 1965) medium differs from the MS (MURASHIGE \& SKOOG, 1962) medium because it contains no nicotinic acid, pyridoxine and the amino acid glycine in addition to containing more of the vitamin thiamine. Not all plants are able to synthesize their own vitamins, so the incorporation of these substances into the environment is an option (SALISBURY \& ROSS, 2012).

Another very important factor in vitro cultivation is light in function of its transmitted radiant energy that is determining in the development of plants and is characterized by photoperiod, irradiance, and spectral composition. Fluorescent lamps, often used in plant growth chambers, have a spectrum of two individual lines of mercury emission superimposed on a continuous spectrum of phosphorus. This light is particularly rich in wavelengths of blue, but can be enriched with red wavelengths (KAPOOR et al., 2018), promoting greater activity of the phytochromotor receptor responsible for controlling photomorphogenic processes.

In addition to physical factors, the biological ones such as dormancy contribute to the impediment of the germinative process and the unevenness in the development of the plants. The dormancy is the inability of germination of the seed due to internal conditions, even if the external ones such as temperature, humidity and atmosphere are adequate (NÉE et al., 2017). In these cases, endosperm hydrolysis is not activated and, in the attempt, to reverse this problem growth regulators such as gibberellic acid and other classes of growth regulators are used.

Exogenous hydrogen peroxide $\left(\mathrm{H}_{2} \mathrm{O}_{2}\right)$ may serve to mobilize energy reserves for the synthesis of hydrolases and promote loosening of the cell wall favoring cell extension (RICHARDS et al., 2015). As gibberellins are indicated as precursors in the breakdown of dormancy and accelerate the germination of non-dormant seeds by promoting the hydrolysis of reserves, acting on the synthesis of RNA and specific proteins of the germination (STENZEL et al., 2003).

Another class of regulators also used in vitro are polyamines that are related to plant growth and have auxin-like effects on cell division and stretching.
ERLAND \& MAHMOUD, (2014) reported that the major in vitro effects of these substances are involved in the regulation of adventitious shoot formation, cell division, flowering and formation of somatic embryos. They are reported in all plants and the most common are putrescine (a diamine), spermidine (a triamine) and spermine (a tetramine).

The present research aimed to evaluate the efficiency of the use of hydrogen peroxide in the pretreatment of lavender seeds. In addition to this, to identify which lamp, culture media and growth regulators favor the germination and initial development of this species.

\section{MATERIALS AND METHODS}

Lavender seeds were disinfected in $70 \%$ alcohol for 1 minute and in a $2.5 \%$ sodium hypochlorite solution for 20 minutes. Seeds were then washed three times with autoclaved distilled water in a laminar flow chamber.

Hydrogen peroxide in pre-treatment of lavender seeds inoculated at different concentrations of gibberellic acid

In this experiment two types of seeds were used, untreated and pretreated in $30 \%$ hydrogen peroxide solution for 24 hours on a shaker table. Subsequently, seeds were inoculated in MS medium (MURASHIGE \& SKOOG, 1962) supplemented with $0.0 ; 1.0 ; 2.0$ or $3.5 \mathrm{mg} \mathrm{L}^{-1}$ of $\mathrm{GA}_{3}, \mathrm{pH}$ adjusted to 5.7 and previously autoclaved at $121{ }^{\circ} \mathrm{C}$ and 1.2 atm for 20 minutes. Transparent glass flasks containing $30 \mathrm{ml}$ of medium were sealed with PVC film and held in a conventional growth room with photoperiod of 16 hours at $25 \pm 2{ }^{\circ} \mathrm{C}$ with light intensity of $52.5 \mu \mathrm{Mm}^{-2} \mathrm{~s}^{-1}$, supplied by white fluorescent lamps.

The experiment was Completely Randomized Design, in a 2 x 4 factorial scheme (untreated and pretreated with $\mathrm{H}_{2} \mathrm{O}_{2} \times 4$ concentrations: $0,1,2$ and $3.5 \mathrm{mg} \cdot \mathrm{L}^{-1}$ of $\mathrm{GA}_{3}$ ), with five replication. Each experimental plot consisted of six vials containing five seeds each.

After 60 days of inoculation, the following parameters were evaluated: germination rate $(\%)$ (seed germinated with radicle and epicotyl protrusions), seedling length $(\mathrm{cm})$, number of leaves and fresh weight $(\mathrm{g})$ of the developed seedlings.

\section{Effect of salt concentrations, culture media and light sources.}

The second was set up in a similar way to the first one but with two different and independent experiments: white fluorescent lamps and Growlux 
lamps featuring two separate and independent experiment due to the difficulty of randomization of the lamp factor and then a statistical analysis was done through the statistical program Genes (CRUZ, 2006).

Seeds were inoculated in test tubes containing MS or LS medium at concentrations of 50 or $100 \%$ of the salts and kept in the growth room under two light conditions: The experiments in white fluorescent and Growlux lamp were of a Randomized Block Design in a $2 \times 2$ factorial scheme, testing 2 medium culture (MS and LS) and 2 concentrations of medium (50 and $100 \%$ of the salts), with five replications. Each experimental plot consisted of ten tubes and each tube contained one seed. The following characteristics were evaluated: shoot length $(\mathrm{cm})$, number of leaves and fresh weight $(\mathrm{g})$, germination rate $(\%)$ and emergence speed of the seedlings.

\section{Plant regulators in different concentrations}

Seeds were inoculated in glass vials containing $30 \mathrm{~mL}$ of LS culture medium with gibberellic acid, spermine, spermidine or putrescine at 0.1 or $0.5 \mathrm{mg} \mathrm{L}^{-1}$ concentrations. The experimental design was completely randomized, in a $4 \times 2$ factorial scheme with 8 treatments (gibberellic acid, spermine, spermidine and putrescine at 0.1 and $0.5 \mathrm{mg} . \mathrm{L}^{-1}$ concentration) with five replications. Each experimental plot consisted of four vials, each containing five seeds. The flasks were placed in the growth room under white fluorescent lamps.

The following characteristics were evaluated at 60 days after inoculation: shoot length $(\mathrm{cm})$, leaf number and germination (\%) of the seedlings.

The data obtained in the four experiments were submitted to statistical analysis of variance using the statistical program Sisvar 4.3 (FERREIRA, 2011). Through the SPSS program, the assumptions of normality of residues, homogeneity of variances and block additivity were tested and they met the ShapiroWilk, Levene and Tukey tests $(\alpha=0.01)$ respectively. A second analysis was performed (Tukey test for qualitative data and polynomial regression for the study of $\mathrm{GA}_{3}$ concentrations $(\alpha=0.05)$.

\section{RESULTS}

Germination percentage of pre-treated seeds with hydrogen peroxide was higher in all concentrations of $\mathrm{GA}_{3}$ with linear pattern and the higher percentage of germination reached $73.09 \%$. Seeds that did not receive pretreatment with $\mathrm{H}_{2} \mathrm{O}_{2}$ reacted also with a linear pattern increasing germination, that is, the higher the concentration of this growth regulator, the higher the percentage of germination, which reached $65.60 \%$ (Figure 1- A).

Seed treatments with hydrogen peroxide resulted in higher values for seedling length, number of leaves and fresh mass. These results demonstrated that $\mathrm{H}_{2} \mathrm{O}_{2}$ favors not only the germination process but also the development of vegetative structures (Figure 1- C).

Among the concentrations of $\mathrm{GA}_{3}$ tested, $2.5 \mathrm{mg} \mathrm{L}^{-1}$ was estimated to be the most favorable for leaf development. Higher concentration act in an antagonistic way to this characteristic, a decrease in the number of leaves and apical necrosis occurring in some plants (Figure 1- B).

No influence of the lamps tested on the evaluated characteristics was observed, except for shoot length of seedlings cultured in MS medium under Glowlux lamps (Table 1). For the number of leaves, fresh mass and germination percentage, it was reported found that in the two light conditions $50 \%$ LS provided generally favorable results for these evaluated characteristics (Table 1). Under Growlux luminous condition the LS 50\% medium resulted in a higher number of seedlings emerged per day compared to the MS medium (Table 1).

Among plant regulators tested in in vitro lavender cultivation, spermidine and putrescine favored leaf production when applied at the highest concentration. However, when spermine was applied at a higher concentration $\left(0.5 \mathrm{mg} \mathrm{L}^{-1}\right)$, it resulted in fewer leaves in the seedlings (Figure 2 - C).

Seedlings with shoot length part (47\%) were formed when cultivated with greater amount of regulators in the medium being an average of 2.20 centimeters against 1.49 centimeters in the lowest concentration (Figure 2 -B). As for the germination of lavender seeds, there was a general increase (34\%) in the presence of higher concentrations of plant regulators in the culture medium (Figure 2 - A).

\section{DISCUSSION}

In the first experiment the increasing linear germination pattern in lavender in the presence of $\mathrm{GA}_{3}$ demonstrated the absence of a phytotoxic effect within the range of concentrations tested. CHETOUANI et al. (2016) also tested a Lavandula specie under similar concentration of $\mathrm{GA}_{3}$ and reported an increase of germination of the same standard reaching $67 \%$ of germination.

In addition to the germinative characteristics, the biometric characteristics of the seedlings were favored by pre-treatment with $\mathrm{H}_{2} \mathrm{O}_{2}$. This is because hydrogen peroxide is a reactive oxygen 


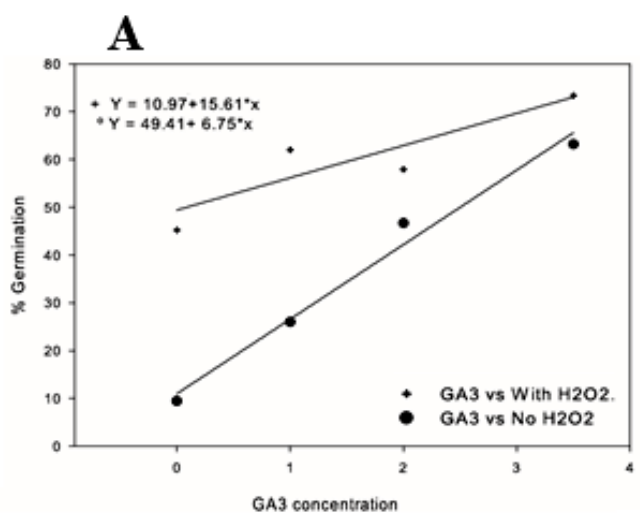

B
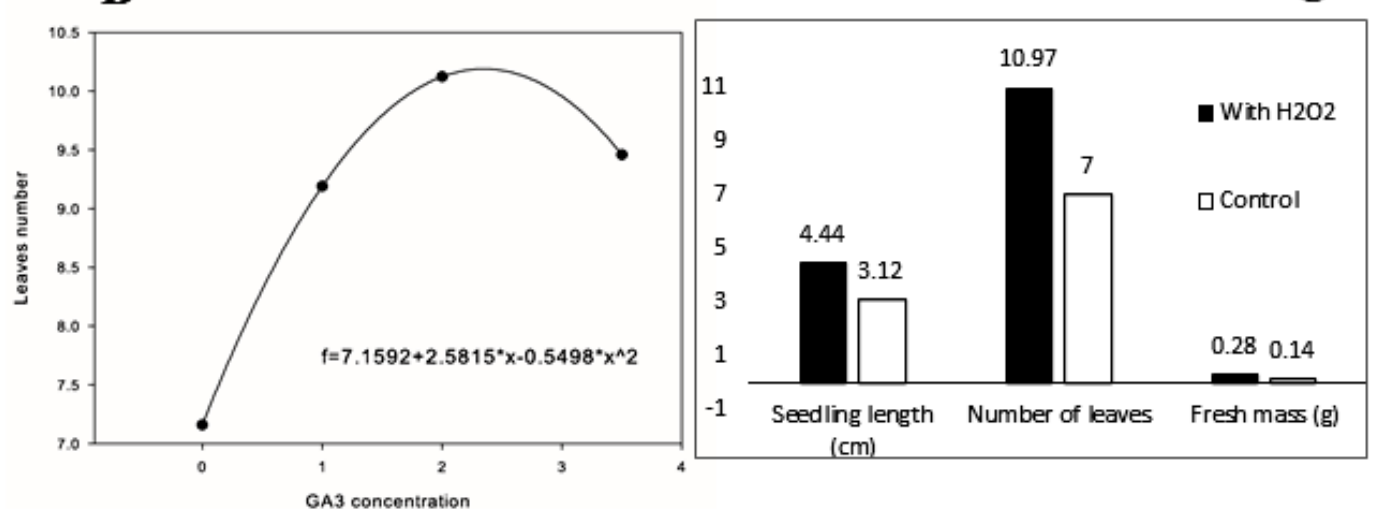

Figure 1 - (A) Percentage of germination of Lavandula angustifolia seeds in vitro submitted to pre-treatment with hydrogen peroxide and control in different concentrations of GA3 $\left(\mathrm{mg} \mathrm{L}^{-1}\right)$, (B) Average number of in vitro seedling leaves as a function of different concentrations of GA3. (C) Average length (cm), number of leaves and fresh mass (g) of seedlings in vitro as a function of seed pretreatment with hydrogen peroxide. Averages followed by distinct letters, differed by Tukey's test at 0.05 significance.

Table 1 - Shoot length, number of leaves, fresh mass, germination and emergency speed of Lavandula angustifolia cultivated in vitro under different light conditions, culture media and concentrations.

\begin{tabular}{lcccccccccc}
\hline \multirow{2}{*}{ Culture media } & \multicolumn{2}{c}{ Shoot length $(\mathrm{cm})$} & \multicolumn{2}{c}{ Number of leaves } & \multicolumn{2}{c}{ Fresh mass (g) } & \multicolumn{2}{c}{ Germination (\%) } & \multicolumn{2}{c}{ Emergency (seedling.day- ${ }^{1}$ ) } \\
\hline & WFL & GRO & WFL & GRO & WFL & GRO & WFL & GRO & WFL & GRO \\
\hline $50 \%$ of MS & $4.06 \mathrm{~A}$ & $1.71 \mathrm{~B}$ & $4.97 \mathrm{~b}$ & $3.17 \mathrm{~b}$ & $0.04 \mathrm{~b}$ & $0.03 \mathrm{a}$ & 53.33 & $56.67 \mathrm{~b}$ & 0.55 & $0.56 \mathrm{~b}$ \\
\hline $100 \%$ of MS & $3.81 \mathrm{~A}$ & $1.51 \mathrm{~B}$ & $6.22 \mathrm{~b}$ & $3.30 \mathrm{~b}$ & $0.05 \mathrm{ab}$ & $0.04 \mathrm{a}$ & 65.00 & $58.33 \mathrm{~b}$ & 0.62 & $0.55 \mathrm{~b}$ \\
$50 \%$ of LS & $5.00 \mathrm{~A}$ & $4.02 \mathrm{~A}$ & $14.28 \mathrm{a}$ & $14.18 \mathrm{a}$ & $0.25 \mathrm{a}$ & $0.15 \mathrm{a}$ & 70.00 & $75.00 \mathrm{a}$ & 0.68 & $0.79 \mathrm{a}$ \\
\hline $100 \%$ of LS & $4.22 \mathrm{~A}$ & $3.10 \mathrm{~A}$ & $10.0 \mathrm{ab}$ & $10.98 \mathrm{a}$ & $0.05 \mathrm{ab}$ & $0.16 \mathrm{a}$ & 60.00 & $63.3 \mathrm{ab}$ & 0.61 & $0.61 \mathrm{ab}$ \\
F(Tukey) & 2.420 & 0.023 & 5.821 & 0.277 & 9.291 & 3.645 & 0.155 & 0.001 & 0.047 & 1.170 \\
W & 0.966 & 0.945 & 0.980 & 0.940 & 0.800 & 0.907 & 0.977 & 0.977 & 0.954 & 0.964 \\
F & 0.134 & 0.309 & 1.723 & 2.783 & 0.848 & 5.596 & 0.023 & 0.982 & 0.184 & 0.543 \\
\hline
\end{tabular}

${ }^{1}$ Averages followed by distinct letters, upper case in the row and lowercase in the column, differ by Tukey test at 0.05 of significance; ${ }^{2} \mathrm{~F}$ (Tukey); W; F: statistics of the Tukey tests for additivity, Shapiro-Wilk and Levene, for white fluorescent light (WFL) and Growlux (GRO) respectively; values in bold indicate treatments and blocks with additive effects, residue normality and homogeneous variances, respectively. 

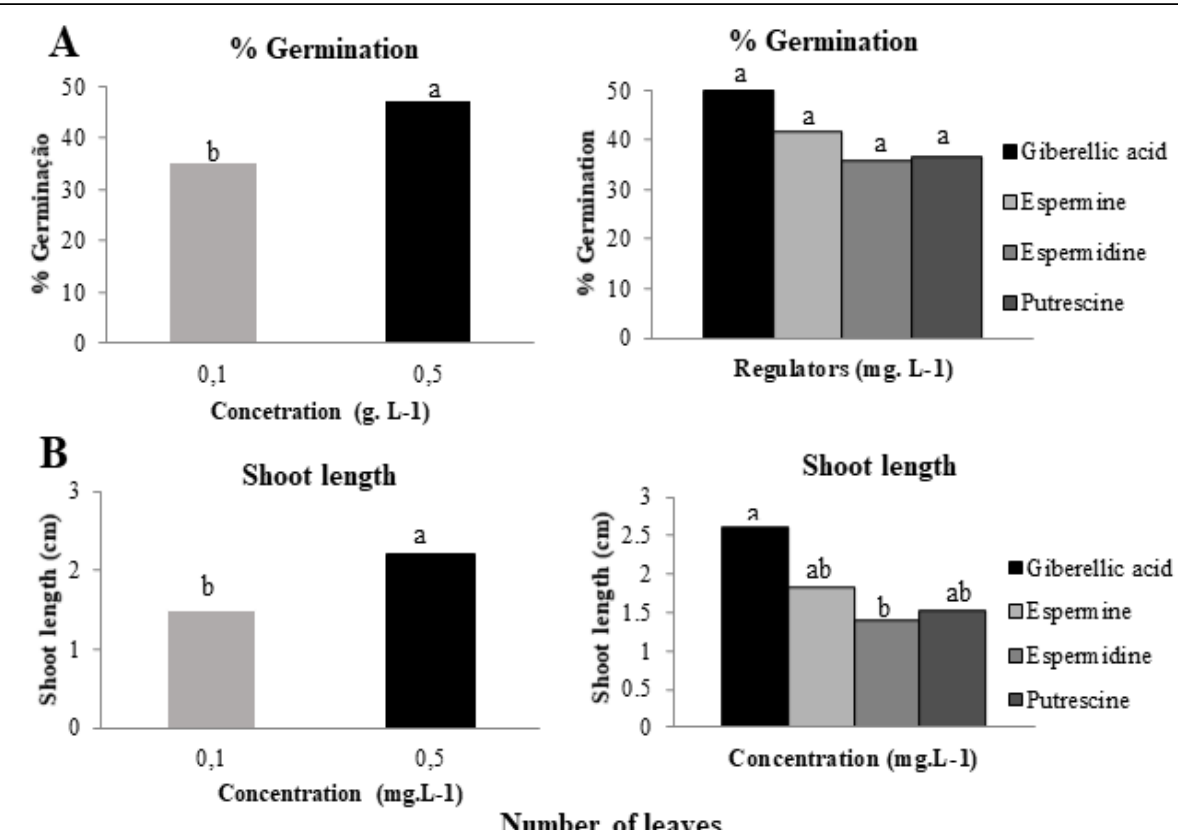

$\mathbf{C}$

Number of leaves

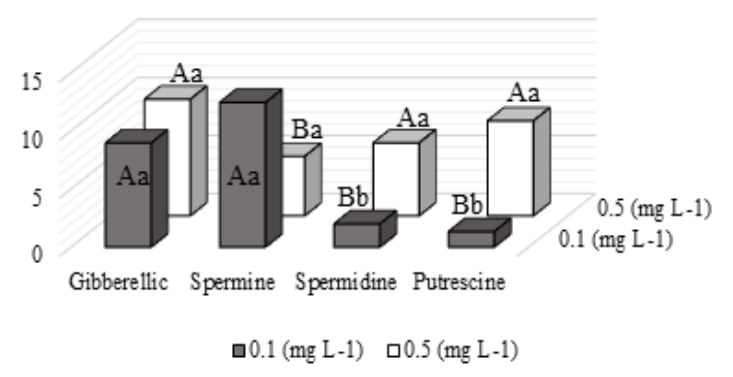

Figure 2 - Percentage of germination (A), shoot length (B) and number of leaves of Lavandula angustifolia seeds in vitro submitted to different regulators and concentrations. Averages followed by distinct letters, differed by Tukey's test at 0.05 significance.

species (ROS) that acts on the cell wall of the seed loosening the bonds by degenerative processes due to the property of being a free radical or generating free radicals. Free radicals are defined as any chemical species capable of independent existence that contains one or more unpaired electrons, thus being highly reactive and capable of attacking any bio-molecule, and of short half-life (SALISBURY \& ROSS, 2012).

Concentration of the $\mathrm{GA}_{3}$ regulator was determinant in the number of leaves produced by lavender seedlings. This is because $\mathrm{GA}_{3}$ modulate several physiological processes in plants improving their photosynthetic efficiency by influencing enzymes involved in photosynthesis, light interception and nutrient absorption as ribulose-1,5-biphosphate carboxylase/oxygenase (RuBisCO), carbonic anhydrase and nitrate reductase (AHMAD et al., 2019).
In the second part, the Growlux lamps employed are composed of bundles of blue and red light that are the most favorable range for photosynthesis, however, they still disadvantaged the lavender species that ended up developing less. Blue light which is intercepted via cryptochrome photoreceptors in shoot tissue signals Cryptochrome Circadian Clock 1 to upregulate gene expression within the gibberellic acid biosynthetic pathway can result a compact growth and reduction of stem elongation. (METALLO, 2018).

Number of leaves produced in the presence of the lowest concentration of LS culture medium was higher. The very high osmotic pressure of the concentrated medium can limit the absorption of water, and the dilution increases the availability of water to the plant. It is important to note that during in vitro cultivation, the solutions of salts and sugars that make 
up the culture media do not exert a purely nutritional effect, but also influence cell growth and morphogenesis through osmotic properties (MALDANER et al., 2006).

Lavender seedlings presented more leaves in LS medium, this behavior was also identified by MACHADO et al. (2013) by testing Lavandula angustifolia $c v$ Provence Blue on MS and LS medium for 40 days. The LS medium, even though it is a medium with less vitamins and amino acids, can providing better conditions, perhaps because of the more favorable osmotic condition or because, for many cultures, amino acids are not essential, and because of the high cost of salts can be dispensed with, provided that the amount of nitrogen and the proportion of nitrate and ammonium ions are correct (TERMIGNONI, 2005).

In the last experiment, the pattern of joint response observed between spermidine and putrescine occurs because spermidine is converted to putrescine through the enzyme polyamine putative oxidase, thus determining patterns of similar responses. TASSONI et al. (2000) verified the effect of spermidine on the activity and regulation of enzyme biosynthesis in different organs of Arabidopsis thaliana L. and the tendency caused by the polyamines in the $0.5 \mathrm{mg} \mathrm{L}^{-1}$ concentration was also reported by this author.

The best effect of $\mathrm{GA}_{3}$ reported in the third experiment also agrees with that found in the first experiment presented here that also tested different concentrations of this regulator with or without pretreatment of hydrogen peroxide.

\section{CONCLUSION}

Pretreatment of lavender seeds with hydrogen peroxide favors gains for all the evaluated characteristics; the use of this treatment is recommended for the in vitro establishment of the species. Use of gibberellic acid promoted higher percentages of germination at the highest concentration, but to obtain seedlings with better qualitative characteristics the concentration of $2.5 \mathrm{mg} \mathrm{L}^{-1}$ was the most adequate. The LS $50 \%$ medium is the one that most favors the morphological and physiological characteristics of plants. The concentration of $0.5 \mathrm{mg} \mathrm{L}^{-1}$ is the most suitable for in vitro culture of L. angustifolia in a medium with gibberellic acid, spermidine or putrescine.

\section{ACKNOWLEDGMENTS}

The authors would like to thank the Coordenação de Aperfeiçoamento de Pessoal de Nível Superior (CAPES), Brazil Finance code 1297878, for the financial support.

\section{DECLARATION OF CONFLICT OF INTERESTS}

The authors declare no conflict of interest. The founding sponsors had no role in the design of the study; in the collection, analyses, or interpretation of data; in the writing of the manuscript, and in the decision to publish the results.

\section{AUTHORS' CONTRIBUTIONS}

All authors contributed equally for the conception and writing of the manuscript. All authors critically revised the manuscript and approved of the final version.

\section{REFERENCES}

AHMAD. B. et al. Concomitant application of depolymerized chitosan and $\mathrm{GA}_{3}$ modulates photosynthesis, essential oil and menthol production in peppermint (Mentha piperita L.). Scientia Horticulturae, v.246, p.371-379, 2019. Available from: <https:// doi.org/10.1016/j.scienta.2018.10.031>. Accessed: Feb. 23, 2019. doi: $10.1016 /$ j.scienta.2018.10. 031.

CHETOUANI, I. et al. Effect of gibberellic acid $\left(\mathrm{GA}_{3}\right)$ on the germination of seeds of Thymus satureioides $\mathrm{L}$ and Lavandula dentata. Journal of Materials and Environmental Sciences, v.8, n.3, p.942-948, 2017. Available from: <https:// www.jmaterenvironsci.com/Document/vo18/vo18_N3/100JMESICMESChetouani.pdf>. Accessed: Feb. 10, 2019.

CRUZ, C.D. Programa Genes: biometria. Editora UFV. Viçosa (MG). 2006. 382p.

DDTD - Direction Departementale Des Territoires De La Drome. Etude stratégique des filieres agricole drômoises. Plantes à Parfum Aromatiques et Medicinales. Available from: <http:// www.drome.gouv.fr/IMG/pdf/Etat_des_lieux_PPAM_2010_ cle54df32.pdf>. Accessed: Jan. 19, 2017.

ERLAND, L.A.E.; MAHMOUD, S.S. An efficient method for regeneration of lavandin (Lavandula x intermedia cv. 'Grosso'). In Vitro Cellular \& Developmental Biology, v.50, n.5, p.646-654, 2014. Available from: $<$ https://link.springer.com/article/10.1007/s11627-0149614-4>. Accessed: Feb. 20, 2019. doi: 10.1007/s11627-014-9614-4.

FERREIRA, D.F. SISVAR - Um sistema computacional de análise estatística. Ciência e Agrotecnologia, v.35. p.1039-1042, 2011. Available from: <http://www.scielo.br/scielo.php?script=sci arttext\&pid $=$ S1413-70542011000600001 $>$. Accessed: Dec. 27, 2018. doi: 10.1590/S1413-70542011000600001.

MACHADO, M.P. et al. In vitro propagation and chemical characterization of the essential oil of Lavandula angustifolia cultivated in Southern Brasil. Ciência Rural, v.43, n.2, p.283289, 2013. Available from: <http://dx.doi.org/10.1590/S010384782013000200015>. Accessed: Apr. 22, 2018. doi: 10.1590/ S0103-84782013000200015.

MALDANER, J. et al. Sacarose e nitrogênio na multiplicação in vitro de Pfaffia glomerata (Spreng.) Pedersen. Ciência Rural, n.36, n.4, p.1201-1206, 2006. Available from: <http://www.scielo.br/ scielo.php?script $=$ sci_arttext\&pid $=$ S0103-84782006000400024 $>$. Accessed:Feb. 10, 2019. doi: 10.1590/S0103-84782006000400024. 
METALLO, R. M. et al. Influence of blue/red vs. white LED light treatments on biomass, shoot morphology, and quality parameters of hydroponically grown kale. Scientia Horticulturae. v.235, p.189-197, 2018. Available from: <https://doi.org/10.1016/j.scienta.2018.02.061>. Accessed: Feb. 10, 2019. doi: 10.1016/j.scienta.2018.02.061.

LINSMAIER, E. M.; SKOOG, F. Organic growth factor requirements of tobacco tissue cultures. Plant Physiology, v.18, p.100-127, 1965. Available from: <https://doi.org/10.1111/j 1399-3054.1965.tb06874.x>. Accessed: Mar. 20, 2019. doi: 10.1111/j.13993054.1965.tb06874.x.

MURASHIGE, T.; SKOOG, F. A revised medium for rapid growth and bioassays with tobacco tissue cultures. Plant Physiology, v.15, p.473-497, 1962. Available from: <https://doi. org/10.1111/j.1399-3054.1962.tb08052.x>. Accessed: Apr. 23 2018. doi: 10.1111/j.1399-3054.1962.tb08052.

NÉE, G. et al. The release of dormancy, a wake-up call for seeds to Germinate. Current Opinion in Plant Biology, v.35, p.8-14, 2017. Available from: <http://dx.doi.org/10.1016/j.pb i.2016.09.002>. Accessed: Mar. 15, 2019. doi: 10.1016/j.pbi.2016.09.002.

RICHARDS, S.L. et al. The hydroxyl radical in plants: from seed to seed. Journal of Experimental Botany, v.66, n.1, p.37-46, 2015. Available from: <https://www. ncbi.nlm.nih.gov/pubmed/25294918>. Accessed: Mar. 19, 2019. doi: 10.1093/jxb/eru398.

KAPOOR, S. et al. Influence of light quality on growth, secondary metabolites production and antioxidant activity in callus culture of Rhodiola imbricate. Journal of Photochemistry and Photobiology B. v.183, p.258-265, 2018. Available from: $<$ https:// www.ncbi.nlm.nih.gov/pub med/29747145>. Accessed: Mar. 14, 2019. doi: 10.1016/j.jphotobiol.2018.04.0 18.2018.

SALISBURY, F.B.; ROSS, C.W. Fisiologia das plantas. Cengage Learning, São Paulo, 2012, 733p.

SPSS. v. 17,00 SPSS. Chicago, Illinois. CD-ROM, 2008

SILVA, S.M. et al. Organo-mineral fertilization effects on biomass and essential oil of lavender (Lavandula dentata L.). Industrial Crops and Products, v.103, p.133-140, 2017. Available from: $<$ https://doi.org/10.1016/j.indcrop.2017.04.004>. Accessed: Apr. 22, 2018. doi: 10.1016/j .indcrop.2017.04.004.

TASSONI, A. et al. Polyamine content and metabolism in Arabidopsis thaliana and effect of spermidine on plant development. Plant Physiology and Biochemistry. v.38, n.5, p.383-393, 2000. Available from: <https://doi.org/10.1016/S0981-9428(00)00757-9>. Accessed: Apr. 22, 2018. doi: 10.1016/S0981-9428(00)00757-9.

TERMIGNONI, R.R. Cultura de tecidos vegetais. UFRGS, Porto Alegre, 2005, 182p.

STENZEL, N.M.C. et al. Superação da dormência em sementes de atemóia e fruta-do-conde. Revista Brasileira de Fruticultura. v.21, p.305-308, 2003. Available from: <http://dx.doi.org/10.1590/ S0100-29452003000200031>. Accessed: Apr. 22, 2018. doi: 10.1590/S0100-29452003000200031. 